\title{
Sequence of a putative human housekeeping gene (HK33) localized on chromosome 1
}

(Alternative polyadenylation; four transcripts; ubiquitous expression; chromosomal location)

\author{
A. Braun ${ }^{\text {a.b }}$, S. Kammerer ${ }^{\text {a }}$, W. Weissenhorn ${ }^{c}$, E.H. Weiss ${ }^{a, c}$ and H. Cleve ${ }^{a, \dagger}$ \\ ${ }^{a}$ Institute of Anthropology and Human Genetics, University of Munich, D-80333 Munich, Germany; ${ }^{b}$ Children's Hospital, Laboratory of Molecular \\ Biology, University of Munich, D-80337 Munich, Germany. Tel. (49-89) 5160-3900; and ' Institute of Immunology, University of Munich, \\ D-80336 Munich, Germany. Tel. (49-89) 5996-688
}

Received by H. Zachau: 26 October 1993; Revised/Accepted: 10 January 1994; Received at publishers: 21 April 1994

SUMMARY

A gene (HK33) localized on human chromosome 1 has been detected by crossreaction of its fusion protein with a monospecific antiserum directed against human vitamin-D-binding protein (hDBP; group-specific component). Its cDNA sequence analysis showed no evident homologies neither to the sequence encoding hDBP nor to any other sequence. The largest cDNA clone of $3.2 \mathrm{~kb}$ includes a $897-\mathrm{bp}$ coding region and a large $3^{\prime}$ untranslated region with at least four polyadenylation sites. Further cDNA amplification using PCR demonstrated a total cDNA length of approx. $3.7 \mathrm{~kb}$. Northern blot analysis revealed signals at about $2.2-2.5 \mathrm{~kb}$ and $4.0 \mathrm{~kb}$, the shorter transcripts representing mRNAs using one of the two polyadenylation sites at about $2.0 \mathrm{~kb}$. Synthesis of the 299 -amino-acid polypeptide (33 kDa) in the bacterial host, with subsequent Western blot analysis, verified the sequence-specific recognition by the hDBPspecific antiserum. The search of protein databanks revealed no homology of HK 33 to any known sequence. Since the gene is transcribed in all cells and tissues tested so far, it is a strong candidate for another housekeeping gene.

\section{INTRODUCTION}

The gene encoding the human vitamin-D-binding protein (hDBP) is known for its high level expression in the liver (Prunier et al., 1964). However, Mc Leod and Cooke (1989) detected low level transcription of the DBP gene of the rat in several other cells and tissues, including kidney, testis and placenta. This observation prompted us to try to identify hDBP in placenta by an immunologi-

Correspondence to: Dr. E.H. Weiss, Institute of Anthropology and Human Genetics, University of Munich, Richard Wagner Street 10/I, D-80333 Munich, Germany. Tel. (49-89) 5203-267; Fax (49-89) 5203-286.

'Deceased January 17, 1994.

Abbreviations: aa, amino acid(s); $\beta M E, \beta$-mercaptoethanol; bp, base pair(s); cDNA, DNA complementary to RNA; E., Escherichia; GST, cal screening of a human placenta cDNA expression library in $\lambda \mathrm{gt} 11$ with hDBP-specific antibodies. For that purpose we used a polyclonal hDBP-specific rabbit antiserum prepared in our laboratory which was preabsorbed with albumin and purified by hDBP affinity chromatography. But instead of $\mathrm{hDBP}$, we detected the crossreacting fusion protein of a cDNA clone that showed no evident homologies to hDBP. The aim of our studies was to characterize this cDNA.

glutathione $S$-transferase; (h)DBP, (human) vitamin-D-binding protein; $H K 33$, putative housekeeping gene, encoding a $33-\mathrm{kDa}$ polypeptide; IPTG, isopropyl- $\beta$-D-thiogalactopyranoside; $\mathrm{kb}$, kilobase(s) or $1000 \mathrm{bp}$; nt, nucleotide(s); oligo, oligodeoxyribonucleotide; ORF, open reading frame; $P A G E$, polyacrylamide-gel electrophoresis; $P C R$, polymerase chain reaction; RT, reverse transcription; SDS, sodium dodecyl sulfate; $U T R$, untranslated region(s). 
EXPERIMENTAL AND DISCUSSION

\section{(a) Detection and characterization of a placental $H K 33$ cDNA clone}

To probe a human placenta cDNA expression library in $\lambda g t 11$ (human placenta cDNA library, Clontech Laboratories, Heidelberg, Germany) we used a hDBPmonospecific antiserum. One positive hybridization signal in $200000 \lambda$ clones examined could be verified in the rescreen (screening and subsequent purification steps were performed according to Sambrook et al., 1989). DNA was isolated from this cDNA clone $\lambda \mathrm{P} 1.2$ and digested with EcoRI (Boehringer-Mannheim, Mannheim, Germany), resulting in two insert fragments of 500 and $750 \mathrm{bp}$, respectively. Sequencing of the 1250-bp cDNA revealed a 200-bp ORF at the $5^{\prime}$ end (Fig. 1).

\section{(b) Sequence of cDNA clones using different polyadenylation sites}

Since Northern blot results indicated the presence of at least three transcripts $(2.2,2.5$ and $4.0 \mathrm{~kb})$ hybridizing to the $\lambda P 1.2$ insert, various cDNA libraries were screened in order to obtain full-length cDNA clones representative for the three mRNA species. First, the 1250-bp probe was used to screen the human placental cDNA library again.

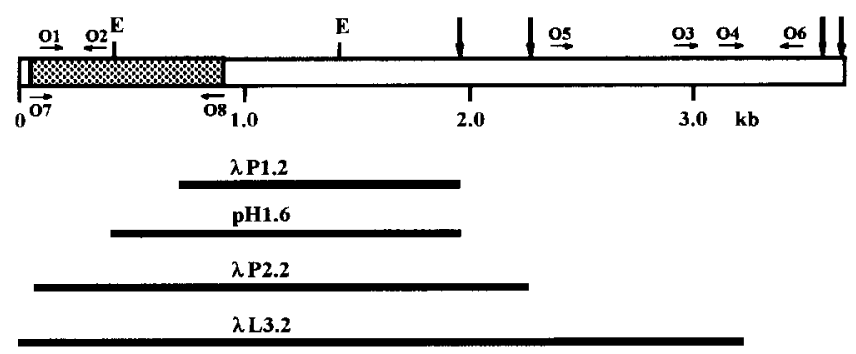

PL/PP/PO

Fig. 1. Scheme of the $H K 33$ cDNA. The structure has been deduced from the cDNA clones $\lambda \mathrm{P} 1.2$, placenta clone $(1.2 \mathrm{~kb}), \mathrm{pH} 1.6$, hepatic clone $(1.6 \mathrm{~kb}), \lambda \mathrm{P} 2.2$, placenta clone $(2.2 \mathrm{~kb}), \lambda \mathrm{L} 3.2$, leukocyte clone $(3.2 \mathrm{~kb})$, and the PCR products amplified at the $3^{\prime}$ end, PL, PP an PO. These products were obtained by PCR, using the more upstream primer $\mathrm{O} 3$, vector-specific reverse primers of $\mathrm{CDNA}$ libraries of different cells and tissues (the leukocyte library in $\lambda Y E S$, the placenta library and an ovary library in $\lambda \mathrm{gt} 11$, Clontech), and $10^{6}$ phages of each library, respectively. After hooster reaction with a nested, e.g., downstream primer O4, products were subcloned in pUC19 and sequenced. The 897-bp coding region is indicated as a shaded box. Alternative poly(A) sites are marked by downward arrows. E, EcoRI sites used for subcloning. Sequences of the primers used for amplification of probes and for chromosomal localization (O1-O2, O5-O6), for amplification of the very $3^{\prime}$ products PL, PP and PO (O3-O4) and for amplification of the coding region (O7-O8) are as follows: O1, 5'-CCTGCAGCCTCTGAGAGC; O2, 5'-GGAATTGGAGGAGCTTCCG; O3, 5'-GTTTGACAGCACCCAAACTG; O4, 5'-GGCAG TCTTTCTCAAACTATG; O5, 5'TATGGTATTGGTGAGGAAGG; O6, 5'-CTTTAAAGTTCGAGAGTCGCA; O7, 5'-AACGCCGCCGCTGAGGAAG; O8, 5'-TCTAGACTCACATGATCAGACACTG.
The EcoRI digest of the largest clone resulted in three cDN $\Lambda$ fragments of about 330,1050 and $800 \mathrm{bp}$, respec tively. These were subcloned in the EcoRI site of pUC 19 (Gibco-BRL, Eggenstein, Germany) (Yanisch-Perron et al., 1985) and transformed in E.coli MC1061 (Meissner et al., 1987). Sequencing demonstrated a total length of 2225 bp and an ORF up to the $5^{\prime}$ end. Furthermore, this cDNA has a large $3^{\prime}$ UTR of 1376 bp which contains two polyadenylation signals.

The first signal at $1960 \mathrm{bp}$ (indicating the first nt of the motif in the sequence submitted to EMBL Data Library) agrees with the consensus sequence 5'-AATAAA (Proudfood and Brownlee, 1976; Proudfood, 1991) and is located 19 bp upstream from the poly(A) tail. This sequence obviously served as poly(A) signal in the $1.6-\mathrm{kb}$ cDNA clone $\mathrm{pH} 1.6$ (Fig. 1) that we detected in a human hepatic cDNA library in the plasmid vector CDM8 (construction of the library has been described by Estaller et al., 1991). The motif $5^{\prime}$-AATATA at nt 2231 that served as recognition site in the clone P2.2 differs in one nt from the consensus sequence and precedes the poly $(\mathrm{A})$ site by $35 \mathrm{bp}$.

As explained later, these two cDNA clones represent the lower Northern blot signal at approx. $2.2-2.5 \mathrm{~kb}$ as the poly(A) tail extends over $200-300 \mathrm{bp}$ in vivo (Manley, 1988).

Using a 290-bp 5' probe (described in Fig. 1) we screened a randomly primed human leukocyte cDNA library in $\lambda$ YES (human leukocyte cDNA stretch library, Clontech Laboratories) to search for larger clones that could account for the $4.0-\mathrm{kb}$ signal. Two clones with a 3.2 and a $2.2-\mathrm{kb}$ insertion, respectively, were obtained.

The $5^{\prime}$ fragment of the $3.2-\mathrm{kb}$ clone $\lambda \mathrm{L} 3.2$ extends the previous cDNA of $\lambda \mathrm{P} 2.2$ by $58 \mathrm{bp}$ and reveals a start codon at nt 11 which was in frame with the ORF of P2.2. It was impossible to obtain cDNA clones with a larger $5^{\prime}$ end, because all clones analysed stopped in the region of nt $1-10$. But it seems probable that the coding region starts at nt 11 , since the sequence flanking the ATG agrees in the most highly conserved positions with the consensus sequence determined by Kozak (1987).

The resulting ORF of 897 bp (Fig. 1) determines a polypeptide of $299 \mathrm{aa}$ ( $32.8 \mathrm{kDa}$ ). The nt sequence of this region together with the deduced aa sequence is presented in Fig. 2. The coding sequence is identical in all cDNA clones analysed.

Sequence analysis of the $3^{\prime} E c^{\prime} O \mathrm{RI} 1.7-\mathrm{kb}$ fragment revealed a $3^{\prime}$ UTR that was $0.9-\mathrm{kb}$ longer than that in the clone $\lambda \mathrm{P} 2.2$, but contained no poly (A) tail. To determine the very $3^{\prime}$ end of the larger transcript, we analysed different PCR products (Fig. 1). All showed a poly(A) tail, but the PCR product derived from one tissue (ovary cDNA library) was 65-bp longer than those of the leuko- 


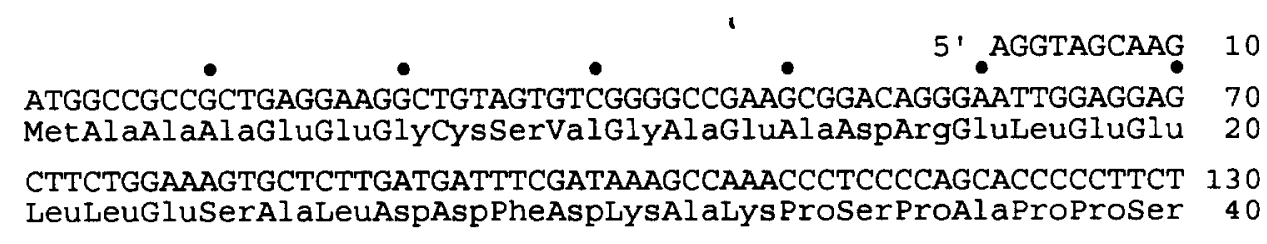

ACCACCACGGCCCCTGATGCTTCGGGGCCCCAGAAGAGATCGCCAGGAGACACTGCCAAA 190 ThrThrThrAlaProAspAlaSerGlyProGlnLysArgSerProGlyAspThrAlaLys 60

GATGCCCTCTTCGCTTCCCAAGAGAAGTTTTTCCAGGAACTATTCGACAGTGAACTGGCT 250 AspalaLeuPheAlaSerGlngluLys PhePheG InGluLeuPheAspSerGluLeuAla 80 TCCCAAGCCACTGCGGAGTTCGAGAAGGCAATGAAGGAGTTGGCTGAGGAAGAACCCCAC 310 SerGlnAlaThrAlagluPheGluLysAlaMetLysGluLeuAlaGlugluGluProHis 100 CTGGTGGAGCAGTTCCAAAAGCTCTCAGAGGCTGCAGGGAGAGTGGGCAGTGATATGACC 370 LeuValGluGInPheGInLYSLeuSerGluAlaAlaGlyArgValGlySerAspMetThr 120 TCCCAACAAGAATTCACTTCTTGCCTAAAGGAAACACTAAGTGGATTAGCCAAAAATGCC 430 SerGlnGlnGluPheThrSerCysLeuLysGluThrLeuSerGIyLeuAlaLysAsnAla 140 ACTGACCTTCAGAACTCCAGCATGTCGGAAGAAGAGCTGACCAAGGCCATGGAGGGGCTA 490 ThrAspLeuGInAsnSerSerMet SerGluGluGluLeuThrLysAl aMetGluGlyLeu 160 GGCATGGACGAAGGGGATGGGGAAGGGAACATCCTCCCCATCATGCAGAGTATTATGCAG 550 GlyMetAspGluGlyAspGlyGluGlyAsnIleLeuProIleMetGlnSerIleMetGln 180

AACCTACTCTCCAAGGATGTGCTGTACCCATCACTGAAGGAGATCACAGAAAAGTATCCA 610 AsnLeuLeuSerLysAspValLeuTyrProSerLeuLysGluI leThrGluLysTyrPro 200

GAATGGTTGCAGAGTCATCGGGAATCTCTACCTCCAGAGCAGTTTGAAAAATATCAGGAG 670 GluTrpLeuGlnSerHisArgGluSerLeuProProGluGlnPheGluLysTyrGlnglu 220

CAGCACAGCGTCATGTGCAAAATATGTGAGCAGTTTGAGGCAGAGACCCCCACAGACAGT 730 GlnHisSerValmet CysLys I leCysGluGlnPheGluAlaGluThrProThrAspSer 240

GAAACCACTCAAAAGGCTCGTTTTGAGATGGTGCTGGATCTTATGCAGCAGCTACAAGAT 790 GluThrThrGlnLysAlaArgPheGluMetValLeuAspLeuMetGlnGlnLeuGlnAsp 260 TTAGGCCATCCTCCAAAAGAGCTGGCTGGAGAGATGCCTCCTGGCCTCAACTTTGACCTG 850 LeuGlyHis ProProLysGluLeuAlaGlyGluMetProProGlyLeuAsnPheAspLeu 280

GATGCCCTCAATCTTTCGGGCCCACCAGGTGCCAGTGGTGAACAGTGTCTGATCATGTGA 910 AspAlaLeuAsnLeuSerGlyProProGlyAlaSerGlyGluGlnCysLeuIleMet * * 299

Fig. 2. The nt and deduced aa sequence of the coding region of the human $H K 33$ gene. Sequencing of double-stranded plasmid template of the clones showed in Fig. 1 was performed by the dideoxy chain-termination method of Sanger et al. (1977) using $\left[\alpha-{ }^{32} \mathrm{P}\right] \mathrm{dATP}$ (Amersham, Braunschweig, Germany), Sequenase Version 2.0 (Tabor and Richardson, 1987; US Biochemical, Bad Homburg, Germany) and universal pUC primers (M13/pUC 'sequencing' and 'reverse sequencing' primer, Boehringer-Mannheim). This sequence and the complete 3 ' UTR sequence (Fig. 1) has been submitted to the EMBL Data Library (accession No. X75535).

cyte and the placenta library, demonstrating additional alternative polyadenylation in this region of the cDNA (Fig. 1).

The poly(A) signal, 5'-AATTAA, at $3566 \mathrm{bp}$, precedes the poly(A) tail by $17 \mathrm{bp}$, while the signal at nt 3612/3624 showed two successive motifs of this sequence and was followed by a poly(A) tail $36 / 24 \mathrm{nt}$ downstream. The fact that these motifs differed from the consensus sequence might explain the reduced amount of the 4.0-kb mRNA in some cells and tissues analysed (Fig. 3A; Sheets et al., 1990).

\section{(c) Northern blot analysis}

To analyse whether the Northern blot signals only differ in the extent of the $3^{\prime} U T R$, further Northern blots were performed (Fig. 3). Hybridization was done with a 290-bp $5^{\prime}$ probe which detected all transcripts of 2.2, 2.5 and $4.0 \mathrm{~kb}$, as expected (Fig. 3A), and with a 1060-bp $3^{\prime}$ probe to confirm that the $4.0-\mathrm{kb}$ transcripts were due to a larger $3^{\prime}$ end caused by alternative polyadenylation (Fig. 3B). Indeed this probe revealed exclusively a single band at $4.0 \mathrm{~kb}$. Different mRNAs are present in varying ratios in all tissues and cells analysed.

\section{(d) Test of different cells and tissues for transcription of HK33}

Many other cells and tissues, including lung, kidney, uterus, colon, ovary, testis, peripheral blood leukocytes, fibroblasts, two hepatoma cell lines (H4, Hep G2) and a retina cDNA library (human fetal retina library in $\lambda$ UniZAP XR vector, Stratagene, Heidelberg, Germany), were tested for the presence of $H K 33 \mathrm{mRNA}$ using RT-PCR. In all these tissues a PCR product of the expected size could be amplified (data not shown). Therefore, the HK33 mRNA seems to be ubiquitously expressed. The protein synthesis will be analysed quantitatively with a mono- 


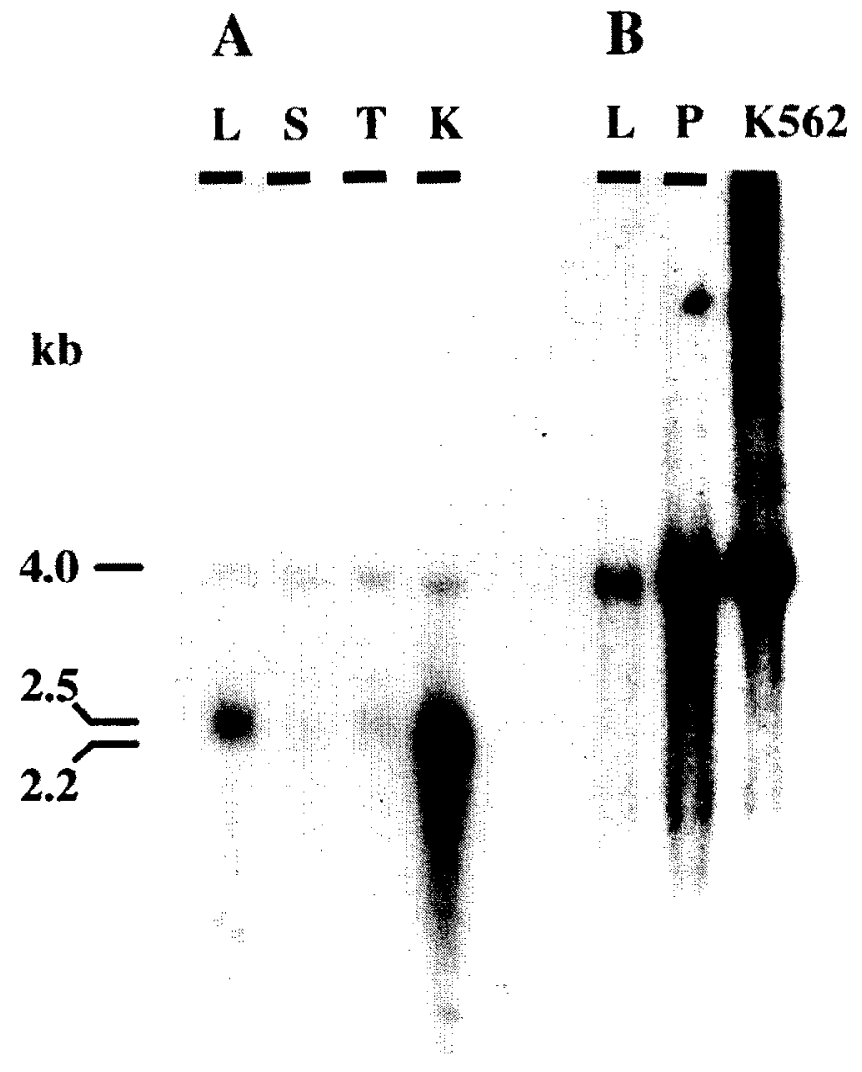

Fig. 3. Northern blot analysis of $H K 33$ transcripts in different cells and tissues. (A) Tissues analysed: $\mathbf{L}$, liver; $\mathbf{S}$, spleen; T, thymus; $\mathbf{K}$, kidney. Hybridization with a 290 -bp 5 probe. The probe was amplified from the 5 region of $\lambda . P 2.2$ using $10 \mathrm{ng}$ of the purified DNA and two insertspecific primers (O1-O2, Fig. 1) and radiolabelled by PCR (Tag polymerase supplied by Promega. Heidelberg, Germany; primers synthesized by MWG Biotech, Ebersberg, Germany) with $\left[x^{32} \mathrm{P}\right] \mathrm{dATP}$ (Amersham). Hybridization was performed overnight by a modified method of Church and Gilbert (1984) at $65 \mathrm{C}$ in a buffer containing $1 \%$ bovine serum albumin (BSA)/7\% SDS $0.25 \mathrm{M} \mathrm{Na}_{2} \mathrm{HPO}_{4} \mathrm{NaH}_{2} \mathrm{PO}_{4}$ $\mathrm{pH}$ 7.2. Filters were washed three times for $10 \mathrm{~min}$ at $65 \mathrm{C}$ with $40 \mathrm{mM}$ $\mathrm{Na}_{2} \mathrm{HPO}_{4} / \mathrm{NaH}_{2} \mathrm{PO}_{4} \mathrm{pH} 7.2 / 1 \%$ SDS. (B) Tissues and cell line tested: L, liver; $P$, placenta; K562, chronic myelogenous leukemia cell line, and hybridization with a 1060 -bp $3^{\prime}$ probe. The probe was amplified by PCR using $200 \mathrm{ng}$ genomic DNA and specific primers (O5-O6. Fig. 1) and radiolabelled by the random priming method (Feinberg and Vogelstein, 1983) using a hexamer mixture, Klenow large fragment of E. coli DNA polymerase I (both Boehringer-Mannheim) and $\left[\alpha^{-32}\right.$ P]dATP (Amersham). Hybridization was performed as in A. RNA was prepared by the procedure of Chirgwin et al. (1979). Total RNA $(10$ to $20 \mu \mathrm{g})$ was separated on $2,2 \mathrm{M}$ formaldehyde $1.2 \%$ agarose gels and transferred to nylon membrane (Hybond-N, Amersham).

specific HK33-antiserum (S.K., A.B. and H.C., data not shown).

\section{(e) Chromosomal localization}

To determine the chromosome encoding the putative housekeeping gene $H K 33$, we performed PCR with a panel of 18 human/rodent hybridoma cell lines. A human cell line and two rodent cell lines (CHO and mouse) were used as controls. PCR was done using $200 \mathrm{ng}$ DNA of each cell line and gene-specific primers (O5-O6, Fig. 1).
The PCR products were examined by Southern blot analysis using the 1060-bp $3^{\prime}$ probe described in Fig. 3B. Four hybridoma cell lines and the human cell line were positive, the other lines including the two rodent cell lines were negative. The positive cell lines contained the human chromosome 1 which was absent in the negative lines. The gene $H K 33$ is, thus, localized on human chromosome 1 (data not shown).

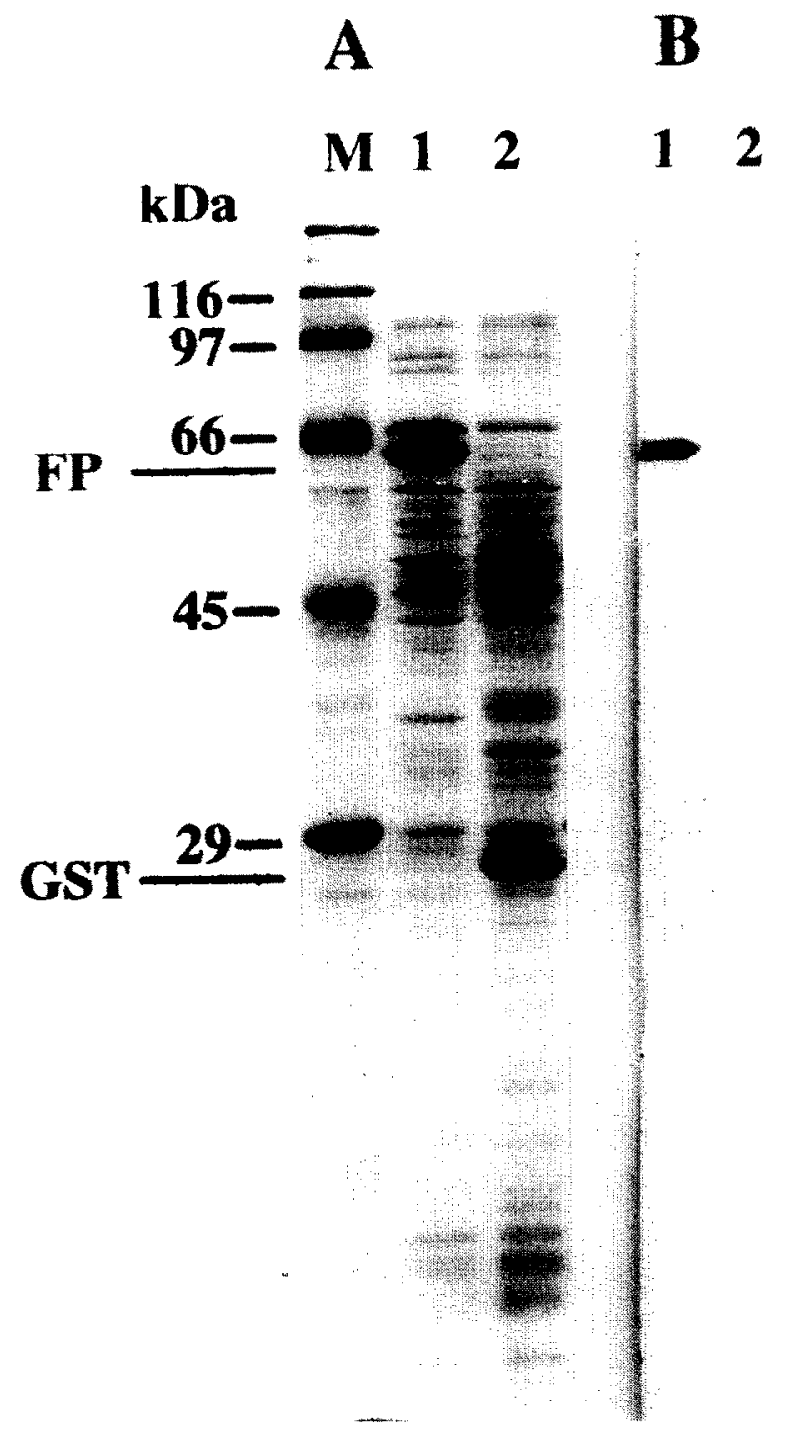

Fig. 4. Expression of HK33 from the prokaryotic vector pGFX-3X (Smith and Johnson, 1988; Johnson et al.. 1989; Pharmacia. Frejburg, Germany). (A) After induction with IPTG (Promega) bacterial growth was continued for $8-10 \mathrm{~h}$. Lysis with a reducing SDS loading buffer containing $\beta \mathrm{ME}$ and separation by a $0.1 \%$ SDS- $12 \%$ PAGE were followed by staining with Coomassie brilliant blue R-250 (Serva, Heidelberg, Germany). M, Markers (MW-SDS-200, Sigma, Deisenhofen, Germany): lane 1. pGEX-3X with $H K 33$ insert producing the 64-kDa fusion protein (FP); lane 2, pGEX-3X without insert producing merely the 26-kDa GST portion (GST). (B) Subsequent Western blot analysis was performed as described in Hoffmann et al. (1990) using the hDBP-monospecific polyclonal antiserum described in the introduction (lane $\mathbf{1}$ and $\mathbf{2}$ as in $\mathbf{A}$ ). 


\section{(f) Synthesis of HK33 in a prokaryotic system}

The coding region of the gene was specifically amplified by PCR using hepatic cDNA and oligos flanking this region (O7-O8, Fig. 1), subcloned in the SmaI site of the prokaryotic expression vector pGEX-3X and transformed into $E$. coli MC1061. The IPTG-induced fusion protein of about $60 \mathrm{kDa}$ consisted of a GST portion of approx. $27 \mathrm{kDa}$ and a $\mathrm{HK} 33$ portion of about $33 \mathrm{kDa}$. Subsequent Western blot analysis confirmed the sequence-specific recognition of the protein HK33 by the hDBP-specific antiserum (Fig. 4).

\section{(g) Conclusions}

(1) The gene HK33 shows no evident homologies to any known nt or aa sequence.

(2) Comparison of the aa sequences of HK33 and hDBP did not show motifs which could be considered as candidates for the immunological cross reaction.

(3) Analysis of different cDNA clones resulted in a fulllength cDNA of about $3.7 \mathrm{~kb}$ with at least four alternative poly(A) sites that are all used in vivo.

(4) Northern blot hybridizations revealed at least two bands which are obviously due to the alternative polyadenylation. Successive sequencing demonstrated a minimum of four transcripts.

(5) Chromosomal localization using a panel of different human/rodent hybridoma cell lines demonstrated $H K 33$ to be located on chromosome 1 .

(6) Transcription of the gene $H K 33$ in all cells and tissues tested so far makes it a candidate for a further housekeeping gene. It is our forthcoming project to determine the exact biological function of this gene.

\section{ACK NOWLEDGEMENTS}

This work was supported by grants of the Deutsche Forschungsgemeinschaft (DFG) to H.C. (Cl 27/14-2) and of the Bundesministerium für Forschung und Technologie (BMFT) to E.H.W. (Genzentrum München).

\section{REFERENCES}

Chirgwin, J.M., Przybyla, A.E., MacDonald, R.J. and Rutter, W.J.: Isolation of biologically active ribonucleic acid from sources enriched in ribonuclease. Biochemistry 18 (1979) 5294--5299.
Church, G.M. and Gilbert, W.: Genomie sequencing. Proc, Natl. Acad. Sci. USA 81 (1984) 1991-1995.

Estaller, C., Koistinen, V., Schwaeble, W., Dierich, M.P. and Weiss, E.H.: Cloning of the 1.4-kb mRNA species of human complement factor $\mathrm{H}$ reveals a novel member of the short consensus repeat family related to the C-terminal of the classical $150-\mathrm{kDa}$ molecule. J. Immunol, 146 ( 1991 ) 3190-3196.

Feinberg, A.P. and Vogelstein, B.: A technique for radiolabeling DNA restriction endonuclease fragments to high specific activity. Anal. Biochem. 132 (1983) 6-13.

Hoffmann, R., Braun, A. and Cleve, H.: A monoclonal antibody against human vitamin-D-binding protein for the analysis of genetic variation in the group-specific component system (Gc). Human Genetics $84(1990) \quad 137-146$.

Johnson, K.S., Harrison, G.B.L., Lightowlers, M.W., O'Hoy, K.L., Cougle, W.G., Dempster, R.P., Lawrence, S.B., Vinton, J.G., Heath, D.D. and Rickard, M.D.: Vaccination against ovine cysticercosis using a defined recombinant antigen. Nature 338 (1989) 585-587.

Kozak, M.: An analysis of 5-noncoding sequences from 699 vertebrate messenger RNAs. Nucleic Acids Res. 15 (1987) 8125-8148.

Manley, J.L.: Polyadenylation of mRN $\Lambda$ precursors. Biochim. Biophys. Acta $950(1988) 1-12$.

McLeod, J.F. and Cooke, N.E.: The vitamin D-binding protein, $\alpha$-fetoprotein, albumin multigene family: detection of transcripts in multiple tissues. J. Biol. Chem. 264 (1989) 21760-21769.

Meissner, P.S, Sisk, W.P. and Berman. M.L.: Bacteriophage cloning system for the construction of directional cDNA libraries. Proc. Natl. Acad. Sci. USA 84 (1987) 41714175.

Proudfood, N.J. and Brownlee, G.G.: $3^{\prime}$ non-coding region sequences in eukaryotic mRNA. Nature 263 (1976) 211-214.

Proudfood, N.J.: Poly(A) signals. Cell 64 (1991) 671-674.

Prunier, J.H., Bearn, A.G. and Cleve, H.: Site of formation of the groupspecific component and certain other serum proteins. Proc. Soc. Exp. Biol. N.Y. 115 (1964) 1005-1007.

Sambrook, J., Fritsch, E.F. and Maniatis, T.: Molecular Cloning. A Laboratory Manual, Cold Spring Harbor Laboratory Press, Cold Spring Harbor, NY, 1989.

Sanger, F., Nicklen, S. and Coulson, A.R.: DNA sequencing with chaintermination inhibitors. Proc. Natl. Acad. Sci. USA 74 (1977) 5463-5467.

Sheets, M.D., Ogg, S.C. and Wickens, M.P.: Point mutations in $\triangle \wedge U \wedge \wedge \Lambda$ and the poly(A) addition site: effects on the accuracy and efficiency of cleavage and polyadenylation in vitro. Nucleic Acids Res. 18 (1990) 5799-5805.

Smith, D.B. and Johnson, K.S.: Single-step purification of polypeptides expressed in Escherichia coli as fusions with glutathione $S$-transferase. Gene 67 (1988) 31-40.

Tabor, S. and Richardson, C.C.: DNA sequence analysis with a modified bacteriophage T7 DNA polymerase. Proc. Natl. Acad. Sci. USA 84 (1987) 4767-4771.

Yanisch-Perron, C., Vieira, J. and Messing, J.: Improved M13 phage cloning vectors and host strains: nucleotide sequence of the M13mp18 and pUC19 vectors. Gene 33 (1985) 103-119. 